\title{
APPLYING RESOURCE DEPENDENCE THEORY AND NETWORK THEORY TO ANALYSIS OF RELATIONSHIP QUALITY BETWEEN LOGISTICS USERS AND PROVIDERS
}

\author{
NGUYEN THI THANH VAN \\ Ho Chi Minh City University of Technology and Education - vanntt@hcmute.edu.vn \\ HO THANH PHONG \\ International University - Vietnam National University, HCMC - htphong@ hcmiu.edu.vn \\ BUI THI THANH \\ University of Economics Ho Chi Minh City - btthanh@ueh.edu.vn
}

(Received: February 21, 2017; Revised: April 07, 2017; Accepted: April 10, 2017)

\begin{abstract}
This study adopts Resource Dependence Theory (RDT) and Network Theory (NT) to explore and measure the factors affecting the relationship quality (RQ) between logistics providers and logistics users in addition to considering the impact of RQ on firm performance. By using the survey data collected from 259 respondents who involved in logistics activities in Ho Chi Minh City from October to December 2015. Testing the conceptual model by Structural Equation Modeling (SEM), we find that partner's importance and network partner knowledge are positively associated with RQ. From the research findings, some recommendations are accordingly proposed.
\end{abstract}

Keywords: Logistics companies; Relationship quality; Resource dependence theory; Network theory; Firm performance.

\section{Introduction}

In Vietnam, the logistics services increasingly assert their important position in the national economy. According to the Ministry of Industry and Trade, within 7 years since Vietnam's accession to the WTO (20072014), the logistics services contribute around $20-25 \%$ of GDP on average per year. It has been maintained over the overall strategic development for the service sector up to 2020 that the logistics services is emphasized as a key factor to promote the development of production and distribution systems of other services, goods flow in country and importexport, growth of the logistics market that reaches $20-25 \%$ per year, and the rate of outsourced logistics that amounts to $40 \%$ (No $175 / \mathrm{Q} Ð \mathrm{TTg})$. In recent years, there has been a rapid increase in the number of logistics companies (from 500 in 2006 to 1300 in 2014) (VLA). However, the majority of enterprises are small, in no collaboration with each other, and their operations are not sustainably oriented (Nguyen Thi Dieu Chi, 2011). Meanwhile, companies that use logistics services do not take into account the long-term relationship. Athanasopoulou (2009) argued that, in such a highly competitive environment, a firm's success will belong to others' because acquiring new customers is five times as costly as keeping existing ones. Therefore, researching the RQ for the logistics-sector companies in Vietnam is of necessity.

The concept of RQ was mentioned in many studies; however, applying RDT and NT to study it in logistics is very rare. Therefore, this study aims to: (1) explore the factors that affect the RQ between logistics user and providers; and (2) examine the impact of the RQ on firm performance from both sides. 


\section{Theoretical Background and Proposed Research Model \\ 2.1. Relationship Quality in Logistics}

Logistics is a term related to the management functions that support a loop material flow: from purchasing and internal control of raw materials to planning and control of work in progress and to purchasing, transport, and distribution of finished products (Jacobs \& Chase, 2014). As enterprises seek solutions to optimize costs, they often outsource some or all logistics activities to external companies, thereby leading to the emergence of logistics providers.

Nowadays, increases in the number and professionalism of logistics companies help their customers save on investment and have more time to focus on core competencies (Cerri, 2012), while the logistics companies themselves find fertile ground to promote this type of service. Therefore, logistics providers and their customers need a RQ. Chu and Wang (2012) define RQ in the context of logistics as the extent to which businesses use the services and logistics service providers to participate in an active and close logistics outsourcing relationship. Thus, the concept should be considered from both perspectives: logistics providers and companies using logistics services (partners).

RQ measurement factors are most used in the studies from 1987 to 2007 in B2B, including trust, satisfaction, and commitment (Athanasopoulou, 2009). In the context of logistics, Chu and Wang (2012) also used these components to measure RQ. This study, therefore, derived from these results, perceived RQ will be measured by three key components: (1) trust; (2) satisfaction; and (3) commitment.

Trust is the willingness of logistics users to rely on their 3PLs, who they believe have prestigious competence and benevolence (Chu \& Wang, 2012). Satisfaction refers to the degree to which logistics users are satisfied with the logistics service overall operation in a logistics outsourcing relationship (Chu \&
Wang, 2012). The commitment is the attitude of the parties in the supply chain toward the development and maintenance of a stable, long-lasting mutual relationship (Zhao et al., 2008).

\subsection{Resource Dependence Theory} (RDT) and Network Theory (NT)

Bolumode (2007) documented that the relationship between logistics companies and partners is governed by two important theories: resource dependence theory (RDT) and network theory (NT), based on which this paper identifies the determinants of RQ.

- Resource dependence theory can be traced to the work of Emerson (1962), analyzing the resource dependence between the parties in the relationship. Therefore, when partners possess important resources that businesses need, this will form the dependence of the business on the partners (Pfeffer \& Salancik, 1978). In logistics, logistics providers become important if they have good capacities to provide services for customers to help them focus on core competencies. Conversely, customers become important if they help logistics companies use resources effectively, explore market opportunities, and increase business performance.

The more important the partners or the less the chance for them to be replaced, the higher the dependence, so businesses will seek closer relations to improve information exchanges, commitment, and legitimacy, to exchange stability and to manage the dependencies (Fink, 2006). Partner's importance also influences the types of cooperation between the parties (Heide \& John, 1990), helps build a long-term, closeknit relationship (Cai \& Yang, 2008), and increases RQ (Chu \& Wang, 2012). Therefore, we propose the first hypothesis:

H1: Partner's importance is positively associated with relationship quality.

- Network theory complements resource dependence theory on how to choose the right partner in a huge network system. 
The network system is established based on the dependence of external resources of firms (Johanson \& Mattsson, 1987), allowing businesses to use the capacity of partners to develop and innovate (Danilovic, 2006). In logistics, according to Bolumole (2007) outsourced logistics occurred when enterprises lack logistics capacity, they try to become in partnership with logistics companies (who have additional capacity which businesses can utilize to achieve their goals). Logistics companies, on the other hand, can also choose good partners who help them maintain and expand the competitive advantage or add value through relationships in the network.

Dyer and Hatch (2006) suggested that substantial benefits can also be gained by having close collaboration with companies that obtain resources. However, to choose the right partner in a large network system, businesses should have sufficient information and knowledge on the partners in the system (Mitrega, 2012). Network partner knowledge should cover organized and structured information with respect to not only a firm's upstream and downstream partners (suppliers and customers), but also competitors who can shape governance structures toward better RQ (Walter et al., 2006). Thus, the second hypothesis can be formulated as follows:

H2: Network partner knowledge is positively associated with relationship quality.

\subsection{Firm performance}

Firm performance involves firms' achievements of their goals during investments in production and business. Measurement of firm performance can be viewed mainly from two aspects: financial and non-financial results (Han, 2009).

Many studies on RQ considered firm performance. For instance, while Lai et al. (2013) showed that the RQ between the buyer and the seller positively affects firm performance, Chu and Wang (2012) argued that logistics-sector companies can use the RQ as a form of dependent management mechanism and improve their performance. Accordingly:

H3: Relationship quality is positively associated with firm performance.

The conceptual model is presented in Figure 1.

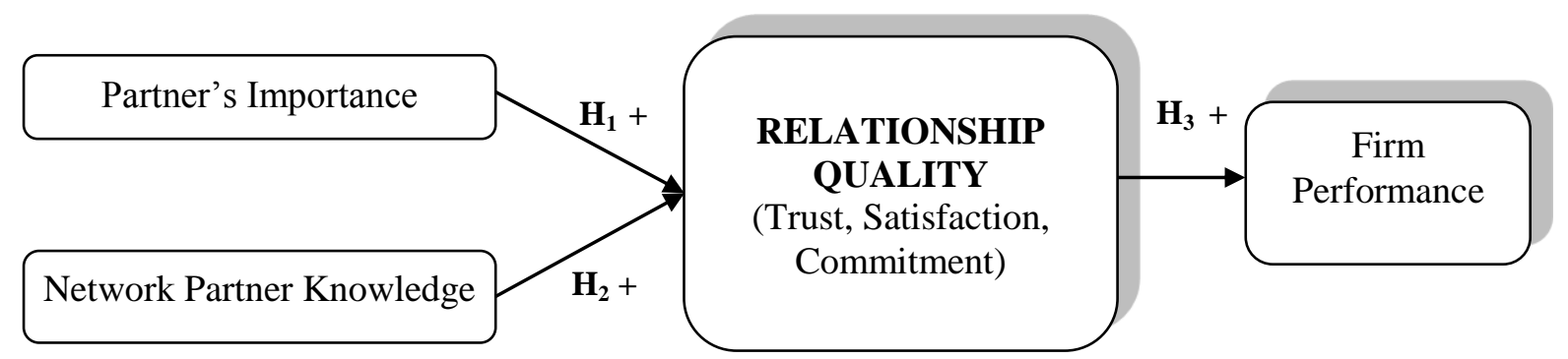

Figure 1. The conceptual model

\section{Research Methodology}

In this study, RQ is considered from both sides: logistics service users and providers. The respondents in the survey comprised of heterogeneous individuals, with different levels of education, economic, and professional levels in logistics activities. Due to certain constrains, only respondents who involve in logistics activities in Ho Chi Minh City, the largest commercial center where many logistics firms conduct their main business activities and have representative offices, were conveniently selected in the sample. The survey used paired questions to achieve the pseudo dyadic information from their customers' side in the relationship. The measurement items were adapted and evaluated from previous studies, namely Chu and Wang (2012), Mitrega (2012), Knemeyer (2004), Nguyen Thi Mai Trang (2004), and Han (2009). In addition, a 7-point Likert scale was used ranging from strongly disagree (1) to strongly agree (7). 


\section{Table 1}

Measurement Items

\begin{tabular}{|c|c|}
\hline $\begin{array}{l}\text { Item } \\
\text { Code }\end{array}$ & Item wording \\
\hline \multicolumn{2}{|c|}{ Partner's Important (PI) } \\
\hline PI1 & $\mathrm{XYZ}$ company is a crucial partner to our future performance \\
\hline PI2 & Our company is a crucial partner to their future performance \\
\hline PI3 & Our relationship with $\mathrm{XYZ}$ company is important to achieve our organizational goals \\
\hline PI4 & Having relationship with us is important to achieve their organizational goals \\
\hline PI5 & If our relationship was to end, our company's operations would be affected \\
\hline PI6 & $\begin{array}{l}\text { XYZ company expects to maintain its relationship with us in order not to affect their } \\
\text { operations }\end{array}$ \\
\hline \multicolumn{2}{|c|}{ Network Partner Knowledge (NPK) } \\
\hline NPK1 & We have sustainable knowledge about activities of XYZ company \\
\hline NPK2 & XYZ company has sustainable knowledge about our activities \\
\hline NPK3 & $\begin{array}{l}\text { We know the intentions of persons and organizations, which influence the success of } \\
\text { our company }\end{array}$ \\
\hline NPK4 & $\begin{array}{l}\text { XYZ company knows the intentions of persons and organizations, which influence its } \\
\text { success }\end{array}$ \\
\hline NPK5 & In logistics, we have complete knowledge about our key partners \\
\hline \multicolumn{2}{|c|}{ Trust (TR) } \\
\hline TR1 & Our company wants to work sincerely with XYZ company \\
\hline TR2 & XYZ company wants to work sincerely with us \\
\hline TR3 & $\begin{array}{l}\text { Our company wants to make beneficial decisions for } \mathrm{XYZ} \text { company under any } \\
\text { circumstances }\end{array}$ \\
\hline TR4 & XYZ company wants to make beneficial decisions for us under any circumstances \\
\hline TR5 & Our company provides assistance willingly for XYZ company without expectation \\
\hline TR6 & XYZ company provides assistance willingly for us without expectation \\
\hline \multicolumn{2}{|c|}{ Satisfaction (SA) } \\
\hline SA1 & We and XYZ company want to create the satisfaction for each other \\
\hline SA2 & Our company is satisfied with the operation process of $\mathrm{XYZ}$ company \\
\hline SA3 & $\mathrm{XYZ}$ company is satisfied with our service quality \\
\hline SA4 & $\mathrm{XYZ}$ company is satisfied with our price \\
\hline \multicolumn{2}{|c|}{ Commitment $(\mathrm{CO})$} \\
\hline $\mathrm{CO} 1$ & We and XYZ company desire to have long-term alliances \\
\hline
\end{tabular}




\begin{tabular}{|l|l|}
\hline $\begin{array}{l}\text { Item } \\
\text { Code }\end{array}$ & \multicolumn{1}{|c|}{ Item wording } \\
\hline CO2 & $\begin{array}{l}\text { We do not consider XYZ company a normal partner, but would like them to be an } \\
\text { important part of us }\end{array}$ \\
\hline CO3 & We feel that XYZ company would also like us to become an important part of it. \\
\hline CO4 & Our relationship deserves to be maintained by all our effort \\
\hline Firm Performance (PER) \\
\hline PER1 & \begin{tabular}{l} 
Our profit has increased in recent years thanks to our relationship with XYZ company \\
\hline PER2
\end{tabular} \begin{tabular}{l} 
XYZ company claims that their profit has increased in recent years thanks to its \\
relationship with us \\
\hline PER3
\end{tabular} $\begin{array}{l}\text { Market share of our company has increased since we have a good relationship with } \\
\text { XYZ company }\end{array}$ \\
\hline PER4 & $\begin{array}{l}\text { XYZ company claims that its market share has increased since it has a good } \\
\text { relationship with us }\end{array}$ \\
\hline PER5 & $\begin{array}{l}\text { XYZ company shows that they have achieved better customer satisfaction since they } \\
\text { used our services }\end{array}$ \\
\hline
\end{tabular}

The conduct of this study follows two steps. Firstly, qualitative research was done through discussions with five experts to identify the factors, and predicated upon the findings of previous studies, the measurement items were constructed and adjusted. Secondly, a quantitative survey via direct interview and/or mail was conducted. A total of 500 questionnaires were delivered from October to December 2015, and 259 with completed information were used in the analysis.

The data were analyzed by SPSS and AMOS software, also applied to test the research hypotheses. The sample structure was shown in Table 2.

Table 2

Characteristics of the survey sample

\begin{tabular}{|l|r|r|l|r|r|}
\hline \multicolumn{3}{|c|}{ Types of supplied services } & \multicolumn{3}{c|}{ Types of companies } \\
\hline \multicolumn{1}{|c|}{ Types } & Quantity (*) & Percentage (\%) & \multicolumn{1}{c|}{ Types } & Quantity & Percentage (\%) \\
\hline Storage & 80 & 30.89 & State Company & 2 & 0.77 \\
\hline Transport & 247 & 95.37 & $\begin{array}{l}\text { Joint stock } \\
\text { Company }\end{array}$ & 70 & 27.03 \\
\hline $\begin{array}{l}\text { Distribution } \\
\text { Customs } \\
\text { Clearance }\end{array}$ & 164 & 16.22 & $\begin{array}{l}\text { Limited } \\
\text { Company }\end{array}$ & 182 & 70.27 \\
\hline $\begin{array}{l}\text { Advice and } \\
\text { Consultancy }\end{array}$ & 136 & 63.32 & $\begin{array}{l}\text { Joint venture } \\
\text { Company }\end{array}$ & 1 & 0.39 \\
\hline Total & 259 & 52.51 & $\begin{array}{l}\text { Alien } \\
\text { corporation }\end{array}$ & 4 & 1.54 \\
\hline
\end{tabular}




\section{Data analysis and results}

\subsection{Testing for Reliability of The Scales}

Before testing the hypotheses, we initially test the measurement items for each of the constructs in the model via Cronbach's alpha. In table 3, the Cronbach's alpha of all scales are rather high (the minimum of CRA is 0.691), and the item-total correlations of all items are also high (the minimum is 0.415). Thus, all measurement items should be tested using Exploratory Factor Analysis (EFA).

\section{Table 3}

Cronbach's Alpha Results of Measurement Items

\begin{tabular}{|l|c|c|c|c|}
\hline \multirow{2}{*}{ Items } & \multicolumn{2}{|c|}{ Number of items } & Cronbach's Alpha & $\begin{array}{c}\text { The smallest item-total } \\
\text { correlation of items }\end{array}$ \\
\cline { 2 - 5 } & Before & After & & 0.647 \\
\hline Partner's Importance & 6 & 5 & 0.857 & 0.530 \\
\hline $\begin{array}{l}\text { Network Partner } \\
\text { Knowledge }\end{array}$ & 5 & 2 & 0.691 & 0.415 \\
\hline Trust & 6 & 5 & 0.777 & 0.564 \\
\hline Satisfaction & 4 & 3 & 0.818 & 0.633 \\
\hline Commitment & 4 & 4 & 0.830 & 0.580 \\
\hline Firm Performance & 5 & 5 & 0.846 &. \\
\hline
\end{tabular}

Exploratory Factor Analysis (EFA) with principal axis factoring in conjunction with promax rotation was conducted to explore dimensionality of factors (construct). The results shown in Table 4 indicate that the minimum of KMO index is 0.67 , that of eigenvalues is 2.2 , and that of total variance explained (TVE) is $48.996 \%$.

\section{Table 4}

EFA Results of Measurement Items

\begin{tabular}{|l|c|c|c|c|}
\hline \multicolumn{1}{|c|}{ Factor } & KMO & $\begin{array}{c}\text { Number of } \\
\text { items }\end{array}$ & Eigen-value & $\begin{array}{c}\text { Total variance } \\
\text { explained }\end{array}$ \\
\cline { 1 - 1 } Partner's Importance & $\begin{array}{c}0.803 \\
(\mathrm{Sig}=0.000)\end{array}$ & 5 & 3.384 & 54.469 \\
\cline { 1 - 1 } $\begin{array}{l}\text { Network Partner } \\
\text { Knowledge }\end{array}$ & $\begin{array}{c}0.730 \\
\text { Trust }\end{array}$ & 4 & 2.425 & 48.996 \\
\cline { 1 - 2 } Satisfaction & $\begin{array}{c}0.676 \\
(\mathrm{Sig}=0.000)\end{array}$ & 3 & 2.200 & 61.800 \\
\cline { 1 - 2 } Commitment & $\begin{array}{c}0.808 \\
(\mathrm{Sig}=0.000)\end{array}$ & 4 & 2.652 & 55.123 \\
\hline Firm Performance & $\begin{array}{c}0.835 \\
(\mathrm{Sig}=0.000)\end{array}$ & 5 & 3.100 & 52.894 \\
\hline
\end{tabular}


The reliability analysis results reveal that these scales receive acceptable Cronbach's alpha (CRA>0.6), and that item-total correlations are relatively high compared to the acceptable level $(>0.3)$. The results of exploratory factor analysis also show that the dimensions proposed for each construct have been demonstrated to be reasonable (KMO $>0.5$; eigenvalues $>1$; and total variance explained $>0.5$ ) (Hair, 1998).

\subsection{Results of Confirmatory Factor Analysis (CFA)}

The results of CFA of the measurement model indicate that the model fits the data well in this case study, including Chi-square = 371.033, df $=371.033$, GFI $=0.893(>0.8)$; TLI $=0.927$ and CFI $=0.936(>0.9)$, Chisquare $/$ df $=1.679(<2)$ and RMSEA $=0.051$ $(<0.8)$. Furthermore, all of the weighted CFA of the observed variables are higher than 0.5, which ensures the convergent validity of the scales (Hair, 1998).

The correlations between constructs together with their $\mathrm{p}$-value indicate that they are significantly different from unity (Table 5). The findings support the across-construct discriminant validity.

\section{Table 5}

Correlations between Constructs

\begin{tabular}{|l|l|c|l|}
\hline Correlation & R & $\begin{array}{c}\text { P- } \\
\text { value }\end{array}$ & Conclusion \\
\hline $\mathrm{PI} \Leftrightarrow \mathrm{RQ}$ & 0.353 & 0.000 & Discriminant \\
\hline $\mathrm{NPK} \Leftrightarrow \mathrm{RQ}$ & 0.275 & 0.000 & Discriminant \\
\hline $\mathrm{RQ} \Leftrightarrow \mathrm{PER}$ & 0.097 & 0.094 & Discriminant \\
\hline
\end{tabular}

Then, we tested the composite reliability coefficients and average variance extracted (AVE) for each construct. The results are provided in Table 6. All of the composite reliability coefficients are higher than 50\% (the minimum is $69.94 \%$ ). Besides, most AVE values are higher than $50 \%$, except that RQ and TR constructs are $47.03 \%$ and $49.93 \%$ respectively.

Generally, the CFA results were adapted with almost all requirements, except for AVE of TR constructs. Hair (1998) argued that as per CFA a model hardly meets all of the standards, and combined with the results of CRA and EFA above, it can be confirmed that all of the scales and constructs employed in this paper are reliable.

\section{Table 6}

Results of Composite Reliability Coefficients and Average Variance Extracted

\begin{tabular}{|c|c|c|c|}
\hline & $\mathbf{N}$ & Composite Reliability Coefficients $\left(\mathbf{p}_{\mathbf{c}}\right)$ & Average Variance Extracted $\left(\mathbf{p}_{\mathbf{v c}}\right)$ \\
\hline RQ & 259 & $72.13 \%$ & $47.03 \%$ \\
\hline TR & 259 & $79.83 \%$ & $49.93 \%$ \\
\hline SA & 259 & $82.73 \%$ & $61.93 \%$ \\
\hline CO & 259 & $83.05 \%$ & $55.09 \%$ \\
\hline PI & 259 & $85.79 \%$ & $54.71 \%$ \\
\hline NPK & 259 & $69.29 \%$ & $53.03 \%$ \\
\hline PER & 259 & $84.73 \%$ & $52.86 \%$ \\
\hline
\end{tabular}

4.3. Testing the research model via Structural Equation Modelling (SEM)

The results of SEM are summarized in Figure 2, in which Chi-square $=376.847$, GFI
$=0.892(>0.8) ;$ TLI $=0.926$, CFI $=0.934$ $(>0.9)$, RMSEA $=0.052(<0.8)$ and Chisquare/df $=1.690(<2)$. 


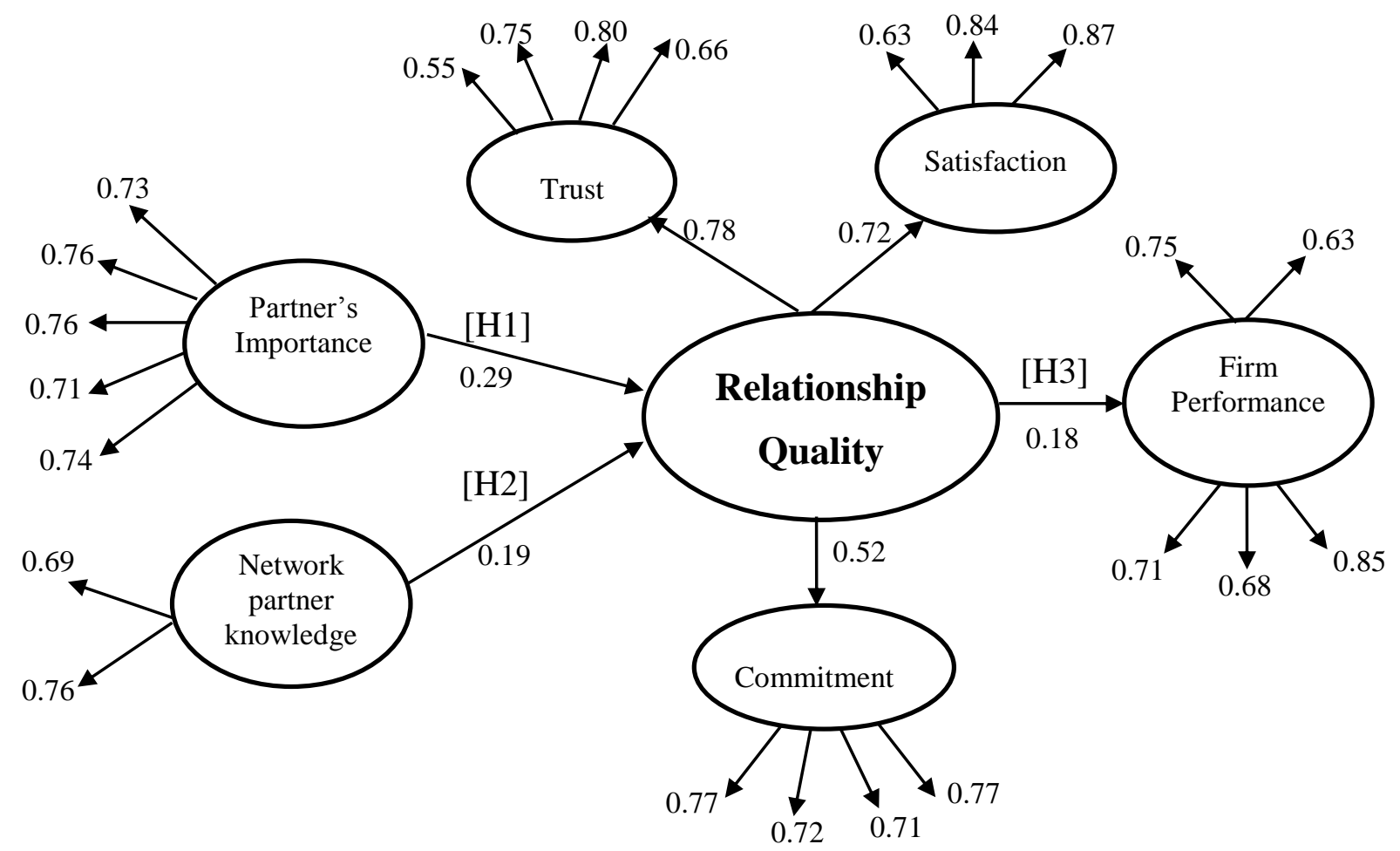

Figure 2. Results of the Theoretical Model (Standardized)

Table 7

Structural Results (Unstandardized Estimates)

\begin{tabular}{|c|c|c|c|c|c|c|c|}
\hline & & & Estimate & SE & Critical & P-value & Hypothesis \\
\hline RQ & $\leftarrow$ & PI & 0.161 & 0.052 & 3.097 & 0.002 & H1 \\
\hline RQ & $\leftarrow$ & NPK & 0.118 & 0.063 & 1.884 & 0.060 & H2 \\
\hline PER & $\leftarrow$ & RQ & 0.156 & 0.087 & 1.798 & 0.073 & H3 \\
\hline
\end{tabular}

\section{Conclusion and Implications}

\subsection{Discussion of results and implications}

Based on structural equation estimations in Table 7, we conclude that the first hypothesis (H1) is supported $(\mathrm{p}<0.05)$, implying that there exists a positive relationship between partner's importance and RQ. The findings show that both logistics users and logistics providers are most likely to develop a high-quality relationship with a partner, who they believe is important to the achievement of their goals. The level of the importance of a partner based on the level of one's dependence on that partner. This is a meaningful thing to logistics suppliers and users. If a logistics company desires to improve its relationship with their customers, it has to enhance the service quality to increase the user's dependence on the services provided. Nowadays, a logistics company is not only a service provider but also a good consultant for clients. If logistics users expect to improve the relationship with logistics providers, they need believe and risk sharing with the partner.

The second hypothesis (H2) on the positive relationship between network partner knowledge and RQ is also supported ( $\mathrm{p}<0.1)$. This implies here that the knowledge about business partners is very important for building 
and improving the relationship, because through that knowledge they can choose the capable partners. Developed network partners knowledge is the antecedent for keeping the balance between keeping close relationships with long-term partners and being open for new promising relationships (Capaldo, 2007). Therefore, enterprises need gather as much upto-date information on their business partners as possible. Enterprises should also show their information in the network, but the information must be reliable, and any distortion of the facts must be avoided.

Finally, the third hypothesis (H3) that a positive relationship is held between relationship quality and firm performance is supported by the survey data $(\mathrm{p}<0.1)$. This finding is important to logistics users and logistics providers since good relationship quality will help them increase profit and market share. This result also reminds logistics managers and managers of the companies who are using logistics services in Vietnam as well as in other developing countries that building, nurturing, and maintaining close and long-term relationships with their partners are priorities in their strategies and policies.

\subsection{Conclusion and limitations}

Based on resource dependence theory (RDT) and network theory (NT), we have proposed a conceptual model with factors that exerts impacts on RQ. At the same time, we have tested the relationship between RQ and firm performance. Using the survey data in Vietnam, the results of this study reveal that logistics companies and logistics users (as well as other companies in general) should try to build and maintain a high - quality relationship, resulting in better firm performance. To create and improve the RQ, they need to be important partners and often gather the information in the network toward choosing good partners. This finding extends the value of RDT and NT in a case study in developing countries.

However, this study has some limitations which leave a gap for future research. Firstly, this study is based on RDT and NT to examine the factors affecting RQ. Future studies can find other theories to explore other factors with their effects on RQ. Secondly, the data were conveniently selected from logistics companies in Ho Chi Minh City, which may be treated as another limitation to the ability to generalize the findings. Future research, therefore, can select a random sample in diverse locations

\section{References}

Athanasopoulou, P. (2009). Relationship Quality: A Critical Literature Review and Research Agenda. European Journal of Marketing, 43, 583-610.

Bolumode, Y.A, Frankel, R., Naslund, D. (2007). Developing a Theoretical Framework for Logistics Outsourcing. Transportation Journal, 2, 35-54.

Cai, S. and Z. Yang (2008). Development of Cooperative Norms in the Buyer-Supplier Relationship: The China Experian. The Journal of Supply Chain Management, 44, 55-70.

Cerri, S. (2012). Exploring Factor Affecting Trust And Relationship Quality In A Supply Chain Context. Journal of Business Studies Quarterly, 4, 74-90.

Chu, Z. and Q. Wang (2012). Drivers of Relationship Quality in Logistics Outsourcing in China. Journal of Supply Chain Management, 48, 78-96.

Danilovic, M. (2006). Bring Your Suppliers into Your Projects - Managing the Design of Work Packages in Product Development. Journal of Purchasing and Supply Management, 12, 246-257.

Dyer, J. H. and N. W. Hatch (2006). Relation-Specific Capabilities and Barriers to Knowledge Transfers: Creating Advantage Through Network Relationships. Strategic Management Journal, 27, 701-19. 
Emerson, R. M. (1962). Power-dependence relations. American Sociological Review, 27, 31-40.

Fink, R.C., L.F. Edelman, K.J. Hatten and W.L. James (2006). Transaction Cost Economics, Resource Dependence Theory, and Customer-Supplier Relationships. Industrial and Corporate Change, 3, 497-529.

Han, J., J.H. Trienekens and S.W.F. Omta (2009). Integrated Information and Logistics Management, Quality Managerment and Firm Performance of Pork Processing Industry in China. British Food Journal, 111, 9-25.

Hair, A. (1998). Multivariable Data Analysis. Prentical-Hall International, Inc.

Heide, J. B. and G. John (1990). Alliances in Industrial Purchasing: The Determinants of Joint Action in BuyerSupplier Relationships. Journal of Marketing Research, 27, 24-36.

Johanson, J. and L-G. Mattsson (1987). Inter-organizational Relations in Industrial Systems - A Network Approach Compared with the Transaction Cost Approach. International Journal of Management and Organization.

Jacob, F. R. and R.B. Chase (2014). Operation Management and Supply Chain. Translate from Jacob' book. Members of Trade-Tourism-Marketing Faculty, 2015. Ho Chi Minh City.

Knemeyer, A. M. and P.R. Murphy (2004). Evaluating the Performance of Third-Party Logistics Arrangements: A Relationship Marketing Perspective. Journal of Supply chain management, 40, 35-51.

Lai, M-C., F-S. Chou and Y-J Cheung (2013). Investigating Relational Selling Behaviors, Relationship Quality and Customer Loyalty in the Medical device Industry in Taiwan. International Journal of Business and Information, 8.

Mitrega, M. (2012). Network Partner Knowledge and Internal Relationships Influencing Customer Relationship Quality and Company Performance. Journal of Business and Industrial Marketing, 27, 486-496.

Nguyen Thi Dieu Chi (2011). Some Issues about Development Policies Logistics Services in Vietnam. Logistics Agonistic and Practical Problems in Vietnam, 389-435. Ha Noi: Publisher National Economic University.

Nguyen Thi Mai Trang., N.J. Barrett and D.T. Nguyen (2004). Cultural Sensitivity, Information Exchange, and Relationship Quality: The Case of Vietnamese Exporters and their Asian vs. European Importers. Journal of Customer Behavior, 3, 281-303.

Pfeffer, J. and G.R. Salancik (1978). The External Control of Organizations - a Resource Dependence Perspective. Harper \& Row publishers.

Prime Minister (2011). Approving the Overall Strategic Development of the Service Sector in Vietnam to 2020 : No. 175/QD-TTg. Hanoi, May 01, 2011.

Walter, A., M. Auer and T. Ritter (2006). The Impact of Network Capabilities and Entrepreneurial Orientation on University Spin-Off Performance. Journal of Business Venturing, 21, 541-67.

Zhao, X., Huo, B., Flynn, B.B., Yeung, J.H.Y. (2008). The Impact of Power and Relationship Commitment on the Integration between Manufacturers and Customers in a Supply Chain. Journal of Operations Management, 26, 368-388. 